\title{
Pemanfaatan Drone dalam Pemetaan Potensi Desa Lekaq Kidau
}

\author{
Dawamul Arifin \\ Teknologi Geomatika, Politeknik \\ Pertanian Negeri Samarinda, \\ Samarinda, 75131 \\ dawamularifin@politanisamarinda.a \\ c.id
}

\author{
Romansah Wumu \\ Teknologi Geomatika, Politeknik \\ Pertanian Negeri Samarinda, \\ Samarinda, 75131 \\ romansah@politanisamarinda.ac.id.c \\ om
}

\author{
Shabri Indra S. \\ Teknologi Geomatika, Politeknik \\ Pertanian Negeri Samarinda, \\ Samarinda, 75131 \\ shabryrockz@gmail.com
}

\begin{abstract}
Abstrak - Pengembangan desa merupakan program prioritas pemerintah. Pengembangan Desa saat ini dilakukan dengan menjadikan desa sebagai subyek dalam pengembangan sehingga diharapkan mampu menjaga kearifan local masyarakat desa dan menjawab kebutuhan masyarakat desa secara langsung. Pengembangan ini dapat dilakukan dengan memetakan potensi desa. Pemetaan potensi desa ini dilakukan dengan tujuan untuk memetakan kondisi, asset dan kebutuhan desa sehingga dapat menjadi dasar dalam melakukan perencanaan pengembangan desa yang berbasis pada potensi desa dan kearifan local masyarakat desa. Pemetaan potensi desa ini dilakukan dengan metode foto udara. Pemotretan udara dilakukan pada ketinggian $150 \mathrm{~m}$ dengan nilai overlap dan sidelap sebesar 80\% menggunakan DJI Phantom 3 Pro. Hasil yang diperoleh menunjukkan bahwa desa lekaq kidau memiliki fasilitas perkantoran, pendidikan, peribadatan, perkantoran dan keamanan desa. Peta penggunaan lahan juga menunjukkan bahwa wilayah desa lekaq kidau sebagian besar masih berupa hutan yakni seluas 110,075 ha. Kondisi ini menunjukkan bahwa desa lekaq kidau memiliki potensi dari pengelolaan wilayah hutan yang besar.
\end{abstract}

Kata Kunci- Foto Udara, Penggunaan Lahan, Potensi Desa.

\section{PEndahuluan}

Secara historis, pembangunan desa telah dilakukan dari waktu ke waktu dan menjadi prioritas pemerintah. Strategi atau kebijakan dalam pembangunan desa tergantung pada periode pembangunan. Perubahan kebijakan yang dilakukan dalam setiap periode pembangunan bertujuan untuk mencari kebijakan atau strategi yang paling efektif. Perkembangan desa sampai saat ini telah memberikan dampak pada perubahan fisik dan perubahan masyarakat. Perubahan fisik dapat dilihat dengan semakin banyaknya desa yang memiliki akses dan menerima sentuhan teknologi/ perkembangan teknologi sedangkan perubahan masyarakat dapat dilihat dari pola/gaya hidup masyarakat yang berubah dari pola hidup tradisional ke pola hidup modern. Kearifan lokal masyarakat desa seperti adanya pola hidup bergotong royong, pola-pola berjuang bersama dalam lingkup desa untuk memenuhi kebutuhan sendiri dilingkup lingkungannya, adanya institusi social yang dapat mendukung pembangunan desa mulai tergerus. Hal ini dikarenakan pengembangan desa yang dilakukan berdasarkan program-program yang dirasa benar dari luar desa dengan kurang atau bahkan tanpa memperhatikan kebudayaan/ kebiasaan masyarakat desa dalam membangun. Masyarakat desa pada akhirnya jauh dari kemandirian dikarenakan mereka dianggap sebagai obyek pembangunan sehingga akan timbul ketergantungan pada program-program pembangunan dari luar desa. Posisi desa yang demikian dapat diminimalisir dengan melakukan pembangunan dan pengembangan desa dengan berdasarkan potensi desa yang ada (Umar, 2019).

Teknologi foto udara dengan menggunakan drone dapat memberikan sebuah gambaran kondisi suatu wilayah melalui pemotretan udara. Gambaran ini merupakan gambaran detil terkait kondisi desa yang selanjutnya dapat digunakan sebagai dasar dalam penyusunan rencana pengembangan desa. Melalui metode ini, potensi desa dapat diidentifikasi dengan baik dan digunakan sebagai dasar dalam merencanakan pengembangan desa berbasis potensi yang ada.

\section{STUDI PUSTAKA}

\section{A. Profil Desa}

Profil desa merepresentasikan kondisi desa yang menjadi informasi atau basisdata dalam pembangunan dan pengembangan desa. Kusumawanto (2018), menjelaskan bahwa dalam Peraturan Menteri Dalam Negeri Nomor 12 Tahun 2007 dalam Kusumawanto 2018 tentang Pedoman Penyusunan dan Pendayagunan Data Profil Desa dan Kelurahan terdapat hal pokok yang harus ada dalam profil desa, yaitu:

1. Potensi SDM (Sumber Daya Manusia)

2. Potensi SDA (Sumber Daya Alam)

3. Potensi Sarana dan Prasarana

4. Potensi Kelembagaan

Potensi Desa dan Kelurahan adalah keseluruhan sumber daya baik sumber daya manusia, sarana dan prasarana, sumber daya alam dan juga kelembagaan yang digunakan untuk mencapai kesejahteraan masyarakat. Mendagri RI (2007), menyatakan bahwa Profil Kelurahan dan Desa adalah keseluruhan informasi mengenai karakter kelurahan dan desa baik informasi terkait potensi sumber daya manusia, sumber daya alam, data dasar 
keluarga, potensi sarana dan prasarana, kelembagaan dan permasalahan serta perkembangan dari kelurahan dan desa yang digambarkan secara utuh dan menyeluruh. Kelompok kerja (Pokja) dibentuk disetiap tingkat baik desa/ kelurahan, kecamatan, kabupaten dan provinsi untuk bertugas dalam penyusunan profil desa dan kelurahan.

\section{B. Foto Udara}

Foto udara atau peta foto adalah peta foto yang diperoleh dengan memperhatikan aturan fotogrametris yang diperoleh melalui pemotretan lewat udara. Foto udara format kecil (FUFK) atau small format aerial photograph merupakan foto yang dihasilkan dari kamera dengan ukuran film atau frame sekitar $24 \mathrm{~mm}$ x $36 \mathrm{~mm}$ dengan panjang fokus $35 \mathrm{~mm}$. Foto udara dengan menggunakan kamera amatir/ non metrik serta menggunakan pesawat sederhana pada dasarnya menggunakan teknologi FUFK (Wolf, 1993). Fotogrametri merupakan pengukuran foto yang dilakukan untuk mengidentifikasi informasi metric mengenai suatu objek (Tao, 2002). Fotogrametri dapat digunakan dalam pemetaan topografi, pemetaan persil dan pemetaan lain yang memerlukan ketelitian tinggi (Suyudi, 2014).

Pada proses interpretasi gambar foto udara selalu diperhatikan kedudukan atau posisi suatu objek dilapangan dan juga selalu diperhatikan bentangan arealnya (Lillesand, Thomas dan Kiefer, 2006). Karakteristik sebuah foto udara perlu dikenali terlebih dahulu agar tidak terjadi kesalahan dalam pengukuran dan interpretasi suatu objek. Foto udara dibedakan menjadi dua yakni foto udara condong dan foto udara tegak/ vertikal (Amrizal, 2016). Pedoman teknis tentang standar ketelitian peta dasar terdapat dalam Perka BIG (Badan Informasi Geospasial) No. 15 th 2014. Ketelitian horizontal dan vertical merupakan komponen ketelitian geometri pada peta dasar (BIG, 2014).bisa dilihat pada gambar 1. Dibawah ini

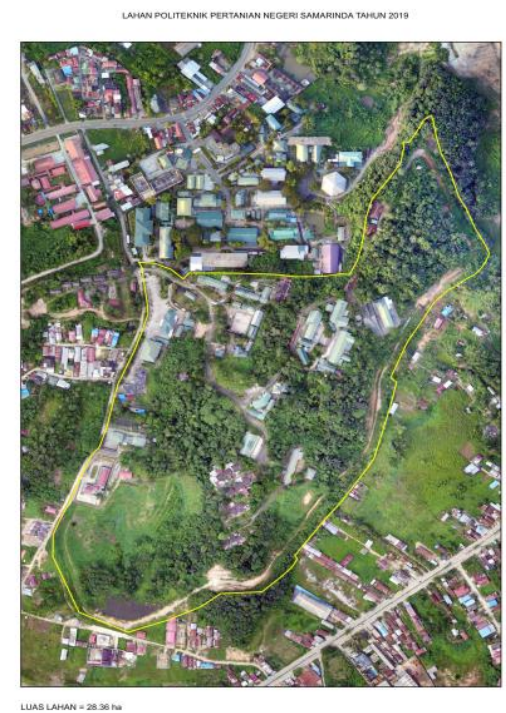

Gambar 1. Peta Batas Foto Udara (sumber: Dawam, 2018)

\section{Unmanned Aerial Vehicle (UAV)}

Pesawat tanpa awak atau UAV (Unmanned Aerial Vehicle) adalah jenis pesawat terbang yang dikendalikan dengan melalui gelombang radio dan memiliki sistem kendali jarak jauh. UAV dapat melakukan suatu program khusus yang diatur dengan karakteristik tertentu. Sistem UAV berbasis elektro mekanik yang dapat dikendalikan oleh pilot dari jarak jauh atau bahkan mampu mengendalikan dirinya sendiri. UAV dapat dikendalikan secara otomatis melalui data yang dimasukkan dalam sensor/system atau bisa juga dikendalikan secara manual dengan menggunakan radio kontrol (Saraoinsong, 2018). Platform ini menggunakan system kamera atau video untuk dapat melakukan pemetaan foto udara skala kecil maupun besar. UAV standar saat ini minimal mampu memberikan system koordinat dalam system global atau local dalam fungsinya saat melakukan foto udara. Oleh karena itu teknologi UAV fotogrametri ini dapat diartikan sebagai alat pengukuran fotogrametri terbaru (Eseinbei, 2009).

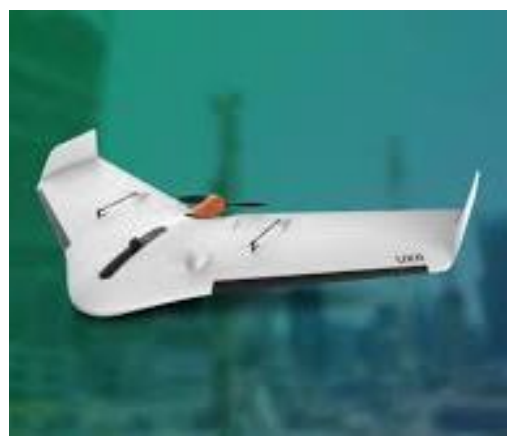

Gambar 2. Contoh UAV

(sumber: zonaspasial.com)

\section{Orthophoto}

Orthofoto adalah gambaran objek yang memiliki posisi ortografik yang benar dan disajikan dalam sebuah foto. Oleh sebab itu, orthofoto secara geometric sebanding dengan peta symbol planimetric dan garis konvensional. Keunggulan orthofoto dibandingkan dengan peta garis adalah orthofoto dapat dikenali dan diidentifikasi dengan lebih baik karena memiliki kualitas piksel foto udara yang tinggi. Selain daripada itu, pengukuran sudut atau jarak dapat dilakukan langsung diatas orthofoto karena orthofoto memiliki ketelitian geometrik yang sangat baik. Kenampakan gambar merupakan perbedaan yang paling utama antara orthofoto dan peta garis. Peta menggunakan symbol garis dalam menampilkan kenampakan suatu objek sedangkan orthofoto terbentuk oleh kenampakan yang sesungguhnya (Nugroho, 2004).

\section{METODOLOGI}

\section{A. Lokasi Penelitian}

Penelitian dilakukan didua lokasi yakni pengambilan data dilapangan dan pengolahan di studio. Untuk pengambilan data, objek yang menjadi daerah penelitian adalah Desa Lekaq Kidau, Kabupaten Kutai Kartanegara. 
Desa ini merupakan desa dengan status desa tertinggal. Sedangkan untuk studio yang digunakan adalah Laboratorium Geomatika, Politeknik Pertanian Negeri Samarinda.

\section{B. Alat dan Bahan}

1. Alat

Adapun alat yang digunakan dalam penelitian ini adalah:

a) Drone DJI Phantom 4

b) Baterai Drone

c) GPS

d) Faststone Photo Resize

e) Agisoft Metashape

f) PCI Geomatika

g) ArcGIS

2. Bahan

Bahan yang digunakan dalam penelitian ini terdiri dari:
a) Terpal
b) Patok Ulin
c) ATK
d) Baterai Drone
e) Baterai Alkaline

3. Diagram Alir Penelitian

Secara rinci, kegiatan penelitian yang dilakukan dapat dilihat pada gambar 3. diagram alir dibawah ini:

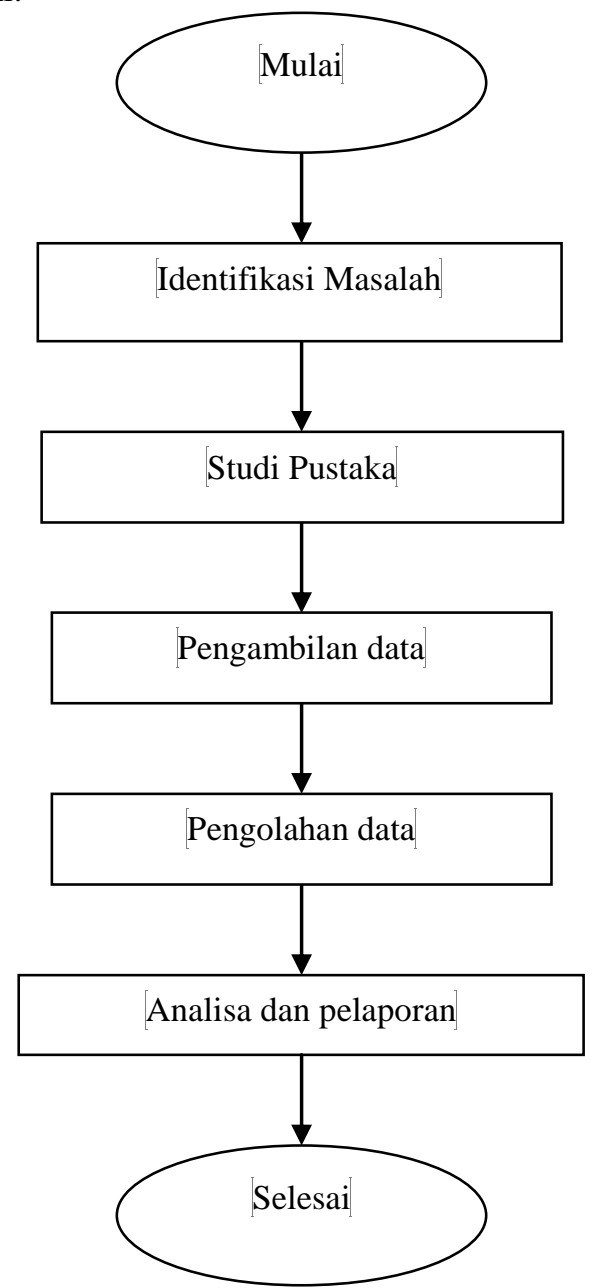

Gambar 3. Diagram Alir Penelitian
Adapun diagram alir penelitian diatas dapat dijabarkan sebagai berikut:

a) Identifikasi Masalah

Identifikasi masalah dilakukan untuk mengkaji kebutuhan penelitian yang akan dilaksanakan. Identifikasi masalah dilakukan dengan orientasi kondisi lapangan secara langsung ataupun tidak langsung. Hasil identifikasi masalah ini adalah rumusan masalah yang akan diangkat untuk dicari jawabannya dalam penelitian.

b) Studi Pustaka

Pada tahap ini dilakukan pengumpulan pustaka-pustaka referensi yang akan digunakan sebagai referensi dalam pelaksanaan kegiatan penelitian baik dalam pengambilan data, pengolahan data dan analisis data.

c) Pengambilan Data

Pengambilan data dilakukan dengan menggunakan wahana drone/UAV. Pengaturan flight dilakukan dengan memanfaatkan software DJI Go dan pix4d. DJI Go digunakan untuk menghubungkan controller dengan drone serta kalibrasi fungsi-fungsi pada drone sebelum diterbangkan. Pix4d digunakan untuk mendesain dengan sidelap dan overlap $80 \%$, kecepatan terbang $10 \mathrm{~m} / \mathrm{s}$ dan tinggi terbang $150 \mathrm{~m}$. Hasil tahap ini berupa foto tegak dari drone.

d) Pengolahan Data

Tahap pengolahan data merupakan tahapan lanjut setelah proses pengambilan data. Pada tahap ini dihasilkan foto-foto sesuai dengan kebutuhan sampai dihasilkan sebuah layout dari data orthophoto. Secara detil tahap pengolahan yang dilakukan adalah sebagai berikut:

\section{Resize Photos}

Proses resize photos dilakukan dengan menggunakan software faststone photo resize. Proses ini dilakukan untuk mengurangi size foto tanpa mengurangi kualitas dari foto tersebut.

2. Align Photos

Proses align photos dilakukan untuk mengidentifikasi posisi kamera dalam pengambilan foto. Hal ini menjadikan fotofoto tersusun secara berurut dan bertampalan sesuai pengambilan dilapangan.

\section{Build Dense Point Cloud}

Tahap ini adalah pembangunan kerapatan titik dari foto-foto yang telah tersusun sebelumnya. Kerapatan titik akan memberikan kedetilan informasi yang mampu dihasilkan dari pengolahan foto tersebut. 
4. Build Mesh

Build mesh dilakukan untuk memperoleh informasi $\mathrm{Z}$ atau ketinggian. Data ini digunakan dalam pembuatan DEM (Digital Elevation Model) baik DTM (Digital Terrain Model) atau DSM (Digital Surface Model).

\section{Build Texture}

Proses build texture dilakukan untuk membangun model fisik 3D. Tahap ini memberikan pilihan untuk menampilkan teksture foto dalam beberapa pilihan bentuk/ model.

\section{Build DEM}

Tahap build DEM dilakukan untuk menggeneralisir nilai tinggi dalam bentuk grid.

\section{Build Orthomosaic}

Proses ini menghasilkan foto tegak dengan resolusi yang tinggi untuk identifikasi visual dari informasi yang ada difoto. Tahap ini menghasilkan data yang selanjutnya dapat digunakan dalam proses spatial analysis.

\section{Layouting}

Proses layouting merupakan tahap untuk menyajikan data secara lebih informatif dan menarik.

\section{e) Analisa dan Pelaporan}

Tahap ini dilakukan untuk memperoleh informasi kondisi dan kebutuhan serta potensi desa. Analisa ini merupakan tahap inti untuk menentukan langkah berikutnya dalam pengembangan desa. Hasil analisis berupa informasi factual dari desa dan rekomendasi kemudian disusun dalam sebuah laporan yang terstruktur.

\section{HASIL DAN PEMBAHASAN}

Pelaksanaan pemetaan potensi Desa Lekaq Kidau, Kecamatan Sebulu, Kabupaten Kutai Kartanegara, Provinsi Kalimantan Timur menghasilkan beberapa hal yakni data foto udara yang dibuat sebuah layout peta. Data foto udara diambil pada tanggal 9 September 2021. Data foto udara ini dihasilkan dengan pemotretan pada ketinggian $150 \mathrm{~m}$ dan tingkat overlap dan sidelap sebesar $80 \%$. Gambar 4. dibawah menunjukkan bahwa desa lekaq kidau memiliki bebrapa fasilitas diantaranya adalah:

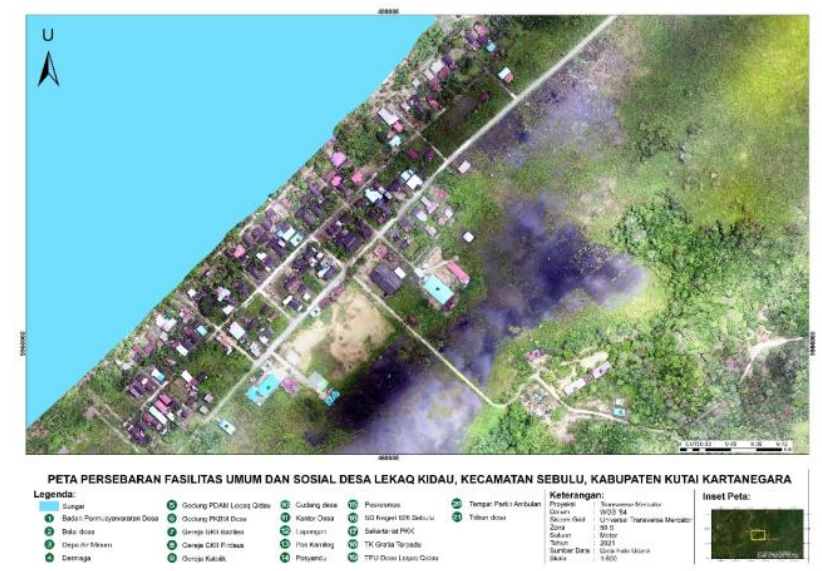

Gambar 4. Peta Persebaran Fasum dan Fasos Desa Lekaq Kidau

Tabel 1. Fasilitas Desa Lekaq Kidau

\begin{tabular}{|c|l|}
\hline No & \multicolumn{1}{|c|}{ Fasilitas } \\
\hline 1 & Kantor Desa \\
\hline 2 & Posyandu \\
\hline 3 & Tempat Parkir Ambulan \\
\hline 4 & Lapangan \\
\hline 5 & Gereja GKII Firdaus \\
\hline 6 & Gudang desa \\
\hline 7 & Gereja Katolik \\
\hline 8 & Tribun desa \\
\hline 9 & Badan Permusyawaratan Desa \\
\hline 10 & Balai desa \\
\hline 11 & Puskesmas \\
\hline 12 & Depo Air Minum \\
\hline 13 & Gereja GKII Bazilea \\
\hline 14 & Gedung PKBM Desa \\
\hline 15 & Dermaga \\
\hline 16 & TK Gratia Terpadu \\
\hline 17 & SD Negeri 026 Sebulu \\
\hline 18 & TPU Desa Lekaq Qidau \\
\hline 19 & Gedung PDAM Leqaq Qidau \\
\hline 20 & Sekertariat PKK \\
\hline 21 & Pos Kamling \\
\hline & \\
\hline
\end{tabular}

Fasilitas dan sarana prasarana yang terdapat di desa lekaq kidau dapat dikelompokkan menjadi fasilitas pendidikan, perkantoran, kesehatan, peribadatan dan keamanan desa. Fasilitas pendidikan yang dimiliki adalah dalam jenjang $\mathrm{TK}$ dan $\mathrm{SD}$ sedangkan fasilitas perkantoran yang ada merupakan perkantoran dalam pelaksanaan tugas administrative desa.

Hasil pemetaan foto udara juga menunjukkan bahwa terdapat beberapa jenis penggunaan lahan yang terdapat di desa lekaq kidau yaitu: 
Tabel 2. Penggunaan Lahan Desa Lekaq Kidau

\begin{tabular}{|c|l|r|}
\hline No & \multicolumn{1}{|c|}{ Penggunaan } & \multicolumn{1}{c|}{$\begin{array}{c}\text { Luasan } \\
\text { (ha) }\end{array}$} \\
\hline 1 & Area pemukiman & 6,114 \\
\hline 2 & Tempat pemakaman umum & 0,203 \\
\hline 3 & Rawa-rawa & 8,953 \\
\hline 4 & Hutan & 110,075 \\
\hline 5 & Jalan & 2,720 \\
\hline 6 & Lahan terbuka & 28,210 \\
\hline 7 & Bangunan & 2,171 \\
\hline 8 & Lapangan & 0,858 \\
\hline 9 & Kebun & 0,694 \\
\hline \multicolumn{2}{|c|}{ Total (ha) } & 159,998 \\
\hline
\end{tabular}

Tabel 2 tersebut juga direpresentasikan dalam sebuah layout sebagaimana dalam gambar 5 dibawah ini.

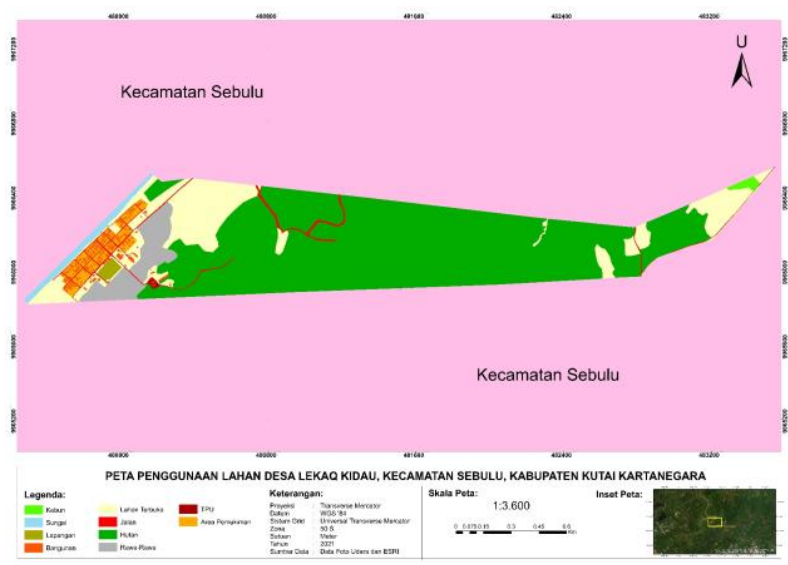

Gambar 5. Peta Penggunaan Lahan Desa Lekaq Kidau

Desa lekaq kidau merupakan salah satu desa di Kecamatan Sebulu, Kabupaten Kutai Kartanegara, Provinsi Kaltim. Desa ini merupakan salah satu desa yang memiliki jarak tempuh kurang lebih $65 \mathrm{Km}$ dari ibukota provinsi. Desa lekaq kidau memiliki wilayah yang dimanfaatkan secara beragam. Penggunaan atau pemanfaatan lahan tersebut dapat dilihat pada tabel 2 dimana pada wilayah desa lekaq kidau didominasi oleh tutupan lahan yang berupa hutan dengan luasan sebesar 110,075 ha. Dominasi tutupan lahan hutan ini menunjukkan adanya potensi pengembangan lahan lebih lanjut yang dapat dilakukan. Penggunaan lahan berikutnya yang mendominasi adalah lahan terbuka dimana luasan penggunaan lahan sebagai lahan terbuka adalah sebesar 28,210 ha. Pemanfaatan lahan terbuka ini adalah sebagai lapangan dan memang lahan yang belum dimanfaatkan oleh masyarakat dan kondisi vegetasinya masih jarang atau bahkan tidak ada. Penggunaan lahan berikutnya adalah sebagai areal rawa-rawa yakni seluas 8,953 ha. Penggunaan lahan lainnya terdiri dari area pemukiman, tempat pemakaman umum, jalan, bangunan, lapangan dan kebun.

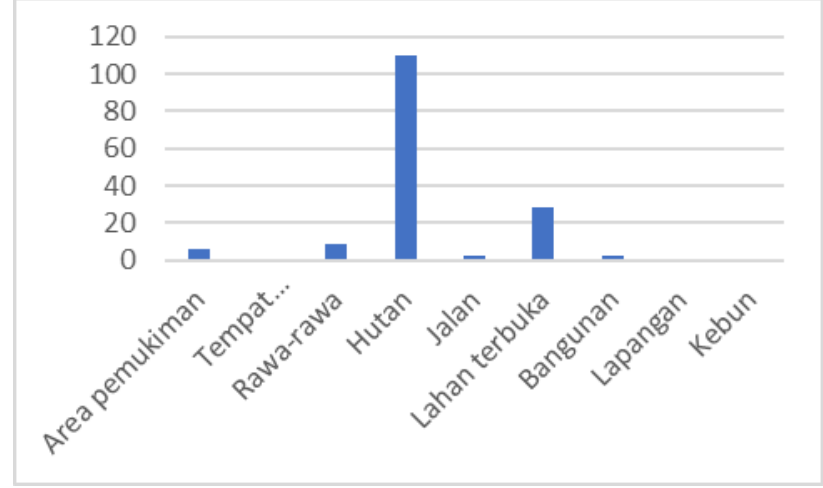

Gambar 6. Grafik Luasan Penggunaan Lahan

\section{KESIMPULAN}

Hasil pembahasan menunjukkan bahwa sarana prasaran dan fasilitas yang dimiliki meliputi fasilitas pendidikan, perkantoran, dan peribadatan serta kesehatan. Penggunaan lahan di desa lekaq kidau terbagi dalam beberapa kelas penggunaan lahan yaitu area pemukiman, tempat pemakaman umum, rawa-rawa, hutan, jalan, lahan terbuka, bangunan, lapangan dan kebun. Penggunaan lahan terbesar di desa lekaq kidau adalah hutan dengan luasan 110,075 ha diikuti oleh lahan terbuka seluas 28,210 ha dan rawa-rawa seluas 8,953 ha. Hal ini menunjukkan potensi pengembangan wilayah di desa lekaq kidau masih sangat besar.

\section{UCAPAN TERIMA KASIH}

Terima kasih diucapkan ke Politeknik Pertanian Negeri Samarinda yang telah membantu pendanaan penelitian ini.

\section{DAFTAR PUSTAKA}

Amrizal. 2016. Teknik Fotogrametri. Medan: Kementerian Pendidikan dan Kebudayaan, Pusat Pengembangan dan Pemberdayaan Pendidik dan Tenaga Kependidikan Bidang Bangunan dan Listrik.

BIG. (2014): Peraturan Kepala Badan Informasi Geospasial Nomor 15 Tahun 2014 Tentang Pedoman Teknis Ketelitian Peta Dasar. Badan Informasi Geospasial (BIG): Cibinong.

Efendi, M. Jauhar. 2020. Buletin Kabar Desa Vol. 3. DPMPD Kaltim.

Eisenbei, H. 2009. UAV Photogrammetry, Thesis Diss, ETH No 18515, Swiss Federal Institute of Technology Zurich.

Hamidi, H. dkk. 2015. Indeks Desa Membangun. Jakarta: Kementerian desa, pembangunan daerah tertinggal dan transmigrasi.

https://idm.kemendesa.go.id/. Dikunjungi pada 25 April 2021. Pkl. 19.48 WITA.

Kusumawanto, Arif. 2018. Pembuatan Profil Desa Pembekalan Mahasiswa KKN Univ. Widya Dharma Klaten. LPPM UGM. 
Lillesand, Thomas M. and Ralph W. Kiefer. 1994. Remote Sensing and Image Interpretation Third Edition. New York: John Wiley \& Sons.

Mendagri RI. 2007. Peraturan Menteri Dalam Negeri Nomor 12 Tahun 2007 tentang Pedoman Penyusunan dan Pendayagunaan Data Profil Desa dan Kelurahan. Direktorat Jenderal Pemberdayaan Masyarakat dan Desa (Ditjen PMD) Kementerian Dalam Negeri RI: Jakarta.

Nain, U. 2019. Pembangunan Desa dalam Perspektif Sosiohistoris. Makassar: Garis Khatulistiwa.

Nugroho Prijono dan Parseno. 2004. Evaluasi Ketelitian Geometri Citra Ikonos Level Geo Daerah Datar Terhadap Peta Orthofoto Skala 1:2500. Universitas Gajah Mada 2004.

Saraoinsong Samuel Hardy, Poekoel C. Vecky. 2018. Rancang Bangun Wahana Pesawat Tanpa Awak (Fixed Wing) Berbasis Ardupilot. Teknik elektro samratulangi Manado 2018.

Suyudi Bambang dan Subroto Tulus. 2014. Fotogrametri dan Penginderaan jauh. Yogyakarta: Sekolah Tinggi Pertanahan Nasional, 55293.

Tao, C.V. (2002). Digital Photogrammtery The Future of Spatial Data Collection. http://geoplace.com/gw/2002/0205/0205dp.asp. diakses 25 April 2021. Pkl. 20.16 WITA

Wolf, Paul R., 1993. Elemen Fotogrametri. Yogyakarta: Gadjah Mada University Press. Terjemahan. Buku asli diterbitkan tahun 1983. 